高濃度フィブリノゲンの接着能

嘉悦 洋* 岡田 政久* 神窪 勇一*

宮本 誠二* 船津 昭信* 大橋 高明*

\title{
Adhesion of fibrinogen at high concentrations
}

Hiroshi KAETSU*, Masahisa OKADA*, Yuichi KAMIKUBO*, Seiji MIYAMOTO*, Akinobu FUNATSU* and Kōmei ŌHASHI*

Key words: fibrinogen, adhesive force, fibrin gels, $\gamma$-chain cross-linking

Fibrin gels formed in the presence of thrombin have exhibited to be able to adhere plastics. This adhesion became a strong with increment of fibrinogen concentrations of the system, whereas changes in the thrombin concentrations gave a constant value. No significant effect of $\mathrm{NaCl}, \mathrm{CaCl}_{2}$ on the fibrin adhesion was observed. However, the adhesion is if anything slightly stronger for a fine than for a coarse gel. In the presence of plasmin, the adhesive force of fibrin became a weak with the degradation of fibrin deposits, indicating that the amount of fibrin clots itself is play a role on the force of adhesion.

An experiment of the fibrin adhesion during gelation process has showed that concomitant with increase in $\gamma$-chain cross-linking as judged by SDSPAGE analysis, there is increase in the adhesive force. During this process, no cross-linking of $\alpha$-chain occurred. These results have suggested that the $\gamma$-chain cross-linking is also important to the fibrin adhesion. This has been also supported by the experiment using Batroxobin which induces $\gamma$ chain cross-linking alone.

は じめに

高濃度フィブリノゲンにトロンビンを添加し
て形成するフィブリンゲルの膠着性に着目し て，それを生体接着剤として臨床応用する研究 が近年行われている1 7). われわれはフィブリ

* 財)化学及血清療法研究所 [广 860 熊本市清水町大窪 668], The Chemo-Sero-Therapeutic Research Institute, Kumamoto, Japan. 
ンゲル形成に影響する種々の因子の接着能に及 ぼす効果を調べた。

\section{I. 方 法}

ヒト・フィブリノゲンは乾燥状態で加熱処 理8)したものを用いた。 その clottability は95\% 以上で，非加熱のものとほぼ同じ性状打よび凝 固能を示した ${ }^{8)}$. 図 2 a に接着の測定法を示し た. 1) フィブリノゲンとトロンビンの混合液 をプラスチック板に一定量塗りゲル化させ，2） 2 時間後にそのプラスチック板を引き剥がすの に必要な“力” $\left(\mathrm{g} / \mathrm{cm}^{2}\right)$ をバネバカリで測定 し,フィブリンゲルの接着能とした.

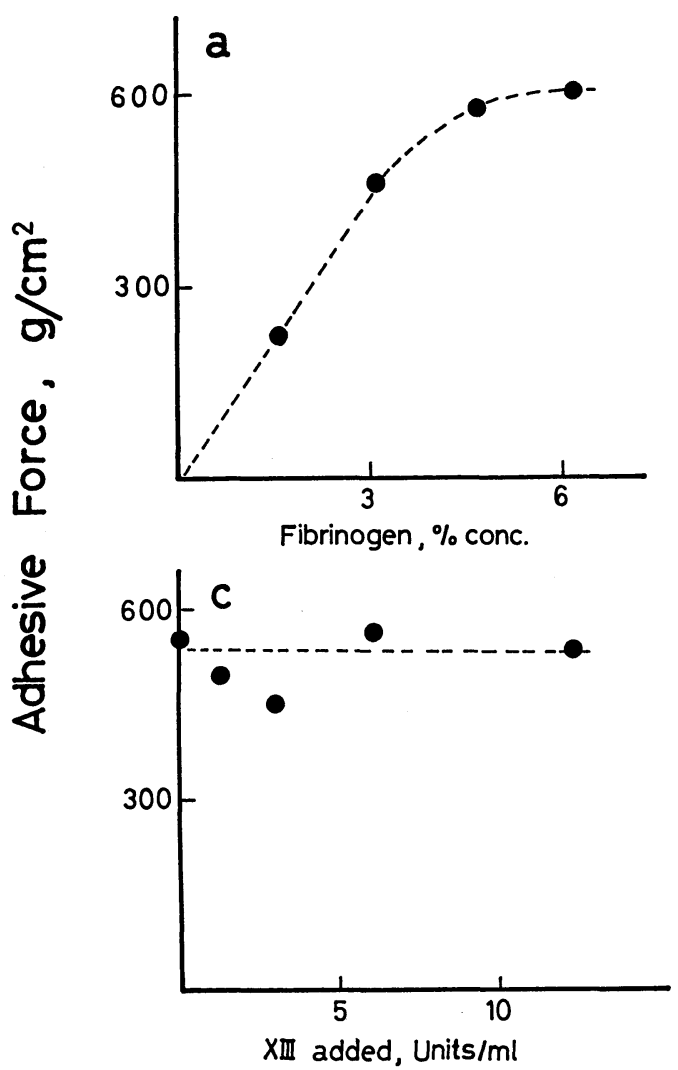

\section{II. 結果および考察}

図 $1 \mathrm{a}$ に示すように, フィブリンゲルの接着 能はフィブリノゲン濃度に依存して増大し, 約 $4 \%$ 以上の濃度で注ぼ一定值となった。 その接 着能は添加するトロンビン濃度には依らず一定 であった（図 1 b). $\mathrm{NaCl}, \mathrm{CaCl}_{2}$ の添加効果は 小さいが，フィブリンゲルを fine 化する条件 は，その接着能を高める傾向を示した。 プラス ミン存在下では, clot 形成後にフィブリンゲル は分解を受けて，そのゲル量が減少し，それに 伴い接着能も低下した（図 1 d). 以上の結果よ り,フィブリンゲルの接着には，トロンビンに よって形成されるフィブリンが重要であること
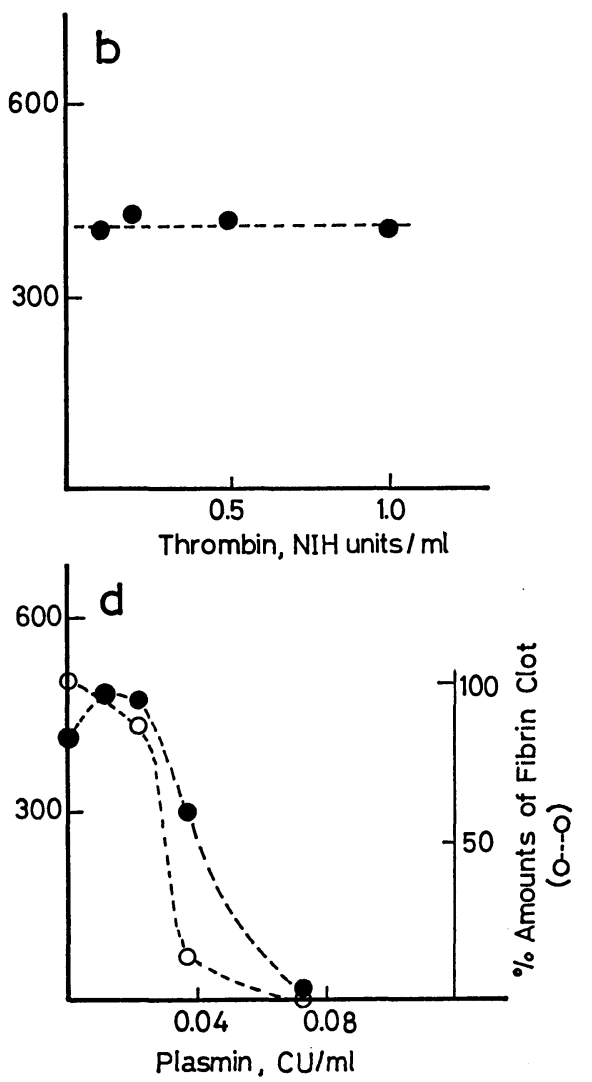

Fig. 1 Adhesive force of fibrin gels.

Fibrin gels were formed between two plastic surfaces and the adhesive force was measured after 2 hours of gelation. Gel formation was as follows: panel a, at different fibrinogen concentrations and $1 \mathrm{NIH}$ unit $/ \mathrm{m} l$ of thrombin. panel $\mathrm{b}$, at different thrombin concentrations and $39 \mathrm{~g} / l$ of fibrinogen. panel c, at different factor XIII concentrations, $40 \mathrm{~g} / l$ of fibrinogen and $1 \mathrm{NIH}$ unit $/ \mathrm{ml}$ of thrombin. Fibrinogen used in this experiment contains $0.15 \mathrm{U}$ of $\mathrm{F} \mathrm{XIII} / \mathrm{mg}$ protein. panel d, at different plasmin concentrations (caseinolytic units $/ \mathrm{m} l$ ), $40 \mathrm{~g} / l$ of fibrinogen and $1 \mathrm{NIH}$ unit/m $l$ of thrombin. 
a

1. fibrin get formation

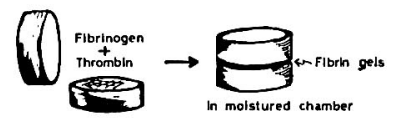

2. measurement of adhesive force

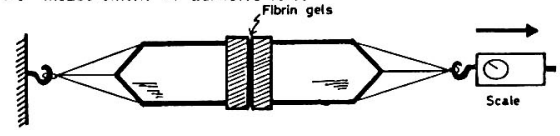

b

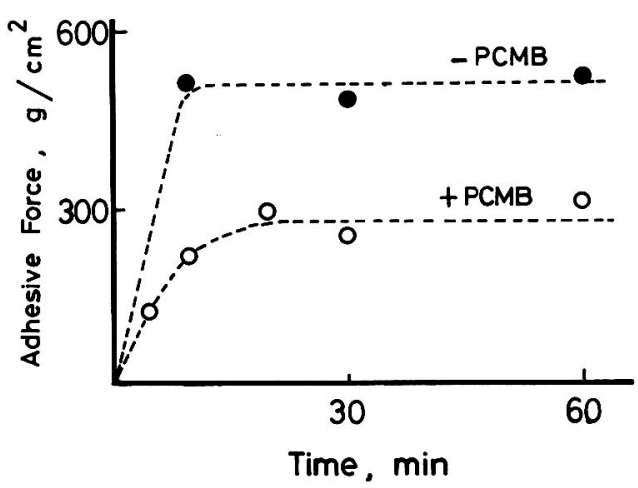

C
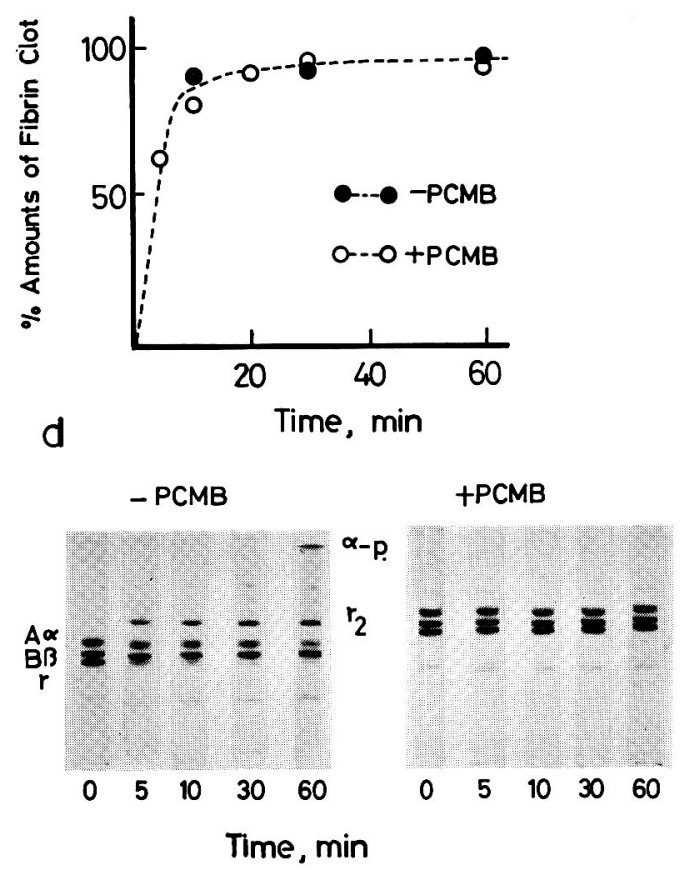

Fig. 2 Time-dependency of adhesive force of fibrin during gelation process. panel a, apparatus for adhesion measurement. panel $b$, effect of PCMB on adhesion of fibrin gels. panel c, amounts of fibrin clot; \% of original proteins. panel d, SDS-PAGE of reduced samples. Fibrinogen, thrombin and parachloromercury benzoate (PCMB) concentrations were $40 \mathrm{~g} / l, 1 \mathrm{NIH}$ unit $/ \mathrm{m} l$ and $0.5 \mathrm{mM}$, respectively.

が確認できた，次に，系に加えるXIII 因子濃度 を増やした場合には，接着能の変化はなく一定 であった（図 1c).これはフィブリンゲルの接 着にはフィブリノゲン中に含まれているXIII因 子濃度で充分であることを示唆している.そこ で, トロンビン添加後の gelation process に拉 ける接着能の変化をゲル量及びフィブリンの 鎖， $\boldsymbol{\alpha}$ 鎖の cross-linking との関連に打いて調 べた（図 2 ）．その接着能は 10 分後に最大值に 達し，その後一定となった。これに対し PCMB 添加でXIII 因子活性を阻害した系9 では，約20 分で一定となり，その最大接着能は PCMB 非 存在の約半分であった（図 2 b). 一方, これら 両系の clot 量にはほとんど差がなかった（図 2c). これらの結果はフィブリンゲルの接着に はフィブリンのみでなく，XIII因子も作用して いることを示している. 図 2d の SDS-PAGE に颃いて, $\mathrm{PCMB}$ 存在下では $\mathrm{A} \alpha, \mathrm{B} \beta, \gamma$ の 3 本鎖に変化はないが，非存在下では時間経過
と共に, $\gamma$ 鎖の減少と $\boldsymbol{\gamma}$ 鎖 dimer の生成がみら れた.この間 $\alpha$ 鎖 polymer の生成はみられな かった，接着力の増大と $\gamma$ 鎖 dimer 形成とが parallel であり，これは $\gamma$ 鎖が接着能に寄与し ている結果と考学られる。事実, $\gamma$ 鎖のみの cross-linking を誘起する Batroxobin"1)によるフ ィブリンゲルはトロンビンの場合とほぼ同程度 の接着能を発揮し， $\gamma$ 鎖の重要さを裏付けてい る.また,この結果はゲル type の異なる Fibrin I ゲルと Fibrin II ゲル10) との接着能に差 がないことを示唆している.

\section{結語}

高濃度フィブリノゲンの接着は，トロンビン により形成するフィブリンのみでなく，XIII因 子に基づく $\gamma$ 鎖の cross-linking が重要である.

\section{文献}

1) Young, J.Z. and Medawar, P.B.: Fibrin 
suture of peripheral nerves; measurement of the rate of regeneration, Lancet, 239; 126 128, 1940.

2) Cronkite, E.P., Lozner, E.L., Deaver, J.M.: Use of thrombin and fibrinogen in skin grafting, J.A.M.A., 124; 976 978, 1944.

3) Tridrick, R.T. and Warner, E.D.: Fibrin fixation of skin transplants, Surgery, 15; 90 95, 1944.

4) Matras, H., Dinges, H.P., Lassman, H., Mamoli, B.: Zur nahtlosen interfascikulären Nerventransplantation im Tier-experiment. Wien. Med. Wochenschr., 122; 517 523, 1972.

5) Spängler, H.P.: Gewebeklebung und lokale Blutstillung mit Fibrinogen, Thrombin und Blutgerinnungs factor XIII. Wien. Klin. Wochenschr., 88 (Suppl. 4) ; 3〜18, 1976.

6) Akrami, R., Kalmar, P., Pokar, H.,
Tilsner, V.: Abdichtung von kunststoff prothesen beim Ersatg der Aorta im thorakalen Bereich, Thoraxchirurgie, 26; 144 147, 1978.

7) Lupinetti, F.M., Stoney, W.S., Alford, W.C., Burrus, G.R., Glassford, D.M., Petracek, M.R., Thomas, C.S.: Cryoprecipitate topical thrombin glue, J. Thorac. Cardiovasc. Surg., 90; 502 505, 1985.

8）平川百合香, 岡田政久, 嘉悦 洋, 宮本誠二, 船津昭信, 大橋高明 : 第 9 回日本血栓止血学 会抄録 138 , 加熱フィブリノゲンの性状. 1986.

9) Okada, M., Blombäck, B., Chang, M.-D., Horowitz, B.: Fibronectin and Fibrin Gel structure, J. Biol. Chem., 260; 1811 1820, 1985.

10) Okada, M. and Blombäck, B.: Factors influencing fibrin gel structure studied by flow measurement, Ann. N.Y. Acad. Sci., 408; 233 253, 1983.

\section{○自分で実際にやれる手術書!}

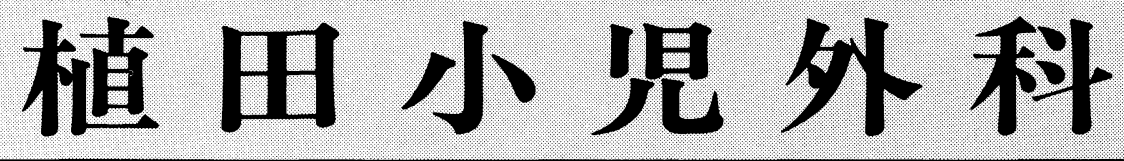

大阪市立保健センター外科 植田隆著

B 5 判 364頁 図207 表18 定価9,800円(干350円)

知識として知っていることと，自分で実際巧くやれるということには随分開きがあるも のである。僅かの小児外科の訓練をうけただけの一般外科医が，どんな症例なら自分でこ なせるか，どんな症例なら専門医に転送しなければならないか，記述の重点を診療の実際 面におき，高名なる著者が実地臨床に役立つことを念じて執筆した名著である。

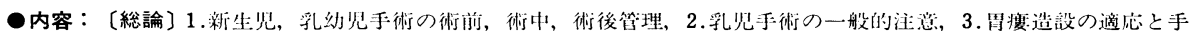

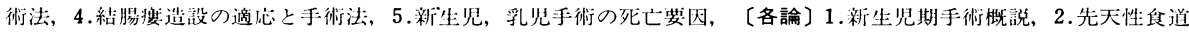

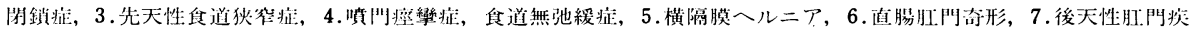

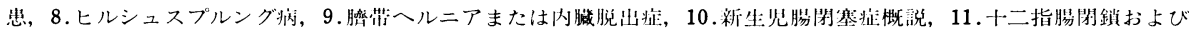

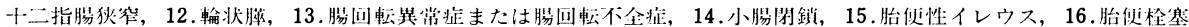

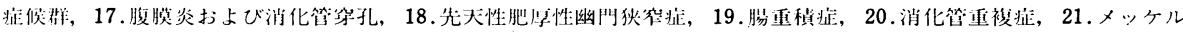

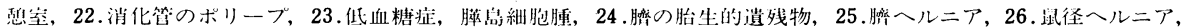

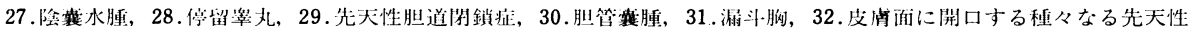

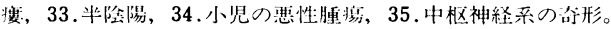

